\title{
Implementation of Management by Objective through Open Performance Review and Appraisal System for Teachers in Tanzania
}

\author{
Rose Ephraim Matete \\ College of Education, University of Dodoma, Tanzania \\ E-mail: roseem2010@gmail.com
}

Received: 07-05- 2016

Accepted: 24-06-2016

Published: 31-07-2016

doi:10.7575/aiac.ijels.v.4n.3p.24

URL: http://dx.doi.org/10.7575/aiac.ijels.v.4n.3p.24

\begin{abstract}
Management by Objective through Open Performance Review and Appraisal System (OPRAS) was introduced in Tanzania for evaluation of public servants work performance in 2004. The aim of this study was to investigate how teachers perceive the implementation of OPRAS as a mechanism of assessing their work performance and making them accountable for their teaching. The study was mainly qualitative with some aspects of quantitative data. It involved 108 informants, where 90 were the primary school classroom teachers, 10 headteachers, 6 school committee members and 2 district educational officials. The data were collected through questionnaires, interviews, and focus group discussion. Some teachers think if OPRAS contract could well be worked out, it could improve the performance; however, there are those teachers who think OPRAS is impractical and unrealistic to the Tanzanian context where pupils are congested in classrooms with shortage of desks. During the school visit in both Kinondoni Dar es Salaam and Mbeya City findings indicated that OPRAS had been abandoned as it created hostility between headteachers and teachers. Teachers complained of the expenses involved in duplicating the copies and the time consumed for discussion. I argue in this paper that although evaluation of teachers is important, the adoption of the type of assessment for their work performance has to be considered because of the nature of the field and the complications involved in dealing with human mind. Teaching is a labour-intensive process. Teachers cannot, by means of their teaching, determine how many pupils will pass a given exam and how well they will do in their exams under the OPRAS requirements.
\end{abstract}

Keywords: Management by objectives, OPRAS, performance, teachers

\section{Introduction}

Management by objectives (MBO) is used in government institutions and social enterprises (Khabakuk \& Shkliarevsky, 1982, p. 115). It became a popular movement in the 1950s, 1960s and 1970s, as advocated by Peter Drucker (Brim, 2012; Errey, 2006). MBO is a "process by which managers establish objectives and measurements for their staff to give them a structure for what they are trying to achieve" (Errey, 2006, p. 1). To Thomas (1998, p. 1), MBO is "a process or system designed for supervisory managers in which a manager and his or her subordinate sit down and jointly set specific objectives to be accomplished within a set time frame and for which subordinates are then held directly responsible". Thomas' definition indicates that a 'subordinate' should be a partner in setting and planning the objectives for her/his tasks.

Errey (2006, p. 3) states that: "Organisational performance is clearly related to how well people are able to perform their jobs. Their performance, in the aggregate contributes to team and department performance indicators, and ultimately corporate objectives". Brady (1973, p. 45) provides two premises underlying MBO. First, that a greater chance of accomplishing the idea is related to the individual's clarity of the idea itself and second, that the real progress of an individual can be evaluated by measuring the extent to which she/he has improved performance. According to Ball $(2003$, p. 219), "the work of the manager [...] involves instilling the attitude and culture within which workers feel themselves accountable and at the same time committed or personally invested in the organisation". Its advocates conceive MBO as a means for promoting effectiveness and efficiency (Lauglo, 1995, p. 18). According to Lauglo, the main aim of $\mathrm{MBO}$ is to make optimal use of the available resources to achieve the goals of the organisation.

\subsection{People and goals}

People are the most important means of managers for achieving the goals and objectives of the organisation (Thomas, 1998, p. 1). According to Thomas, managers must: Possess the ability to instill a sense of commitment and desire towards the contribution of the organisational goal in their subordinates; Have the ability to control and coordinate the efforts of their subordinates for the accomplishment of the agreed goals; and have the ability to help the subordinates to grow in their ability so that they make greater organisational contributions. The MBO advocates, according to Brim (2012, p. 3), believe that: human beings tend to accomplish beyond their normal way of doing things when they use 
goals; human beings respond positively to the goals that they judge as reasonably attainable; and when leaders provide support for a goal, when they model the goal-related behaviour and provide feedback on the progress made, human beings are more likely to attach themselves to the goals.

\subsection{Importance of environmental context for effective performance}

Environmental context in which workers (teachers) work, plays a significant role for effective work performance. As Brim (2012, p. 2) states, the MBO model has been eclipsed because its assumptions neglected some important aspects that are relevant in work environment. According to Brim, in order to incorporate the necessary changes for performing well in the $21^{\text {st }}$ century, instead of focusing on challenges from the manager's perspective, managers need to ask, "What do people need to perform well?" as opposed to asking how best to manage people. This should be done by observing the following: Having a goal and defining the outcomes by using the user experience (a person to whom the manager is responsible in an organisation); developing a logical and flexible action plan and, responding to results based on individual adaptations and adoptions.

The emphasis on an objective alone is, however, not enough. According to Brim (2012, p. 5), people need a goaldefinition process that is specific and strategic, measurable, attainable, reasonable/relevant and time bound (SMART), which means managing by SMART objectives. Other weaknesses of the MBO, as outlined by Brim, include a strong focus on goals and an underestimation of the importance of the environmental context in influencing human behaviour. Murphy (2010, p. 1) suggests that a goal needs to be heartfelt, animated, required and difficult (HARD):

- Heartfelt: Achieving the goal depends on being certain about what one wants more than anything else. If one does not care about the goal, then one cannot have much motivation as regards its achievement.

- Animated: Visualising and imagining by making a goal vivid and alive in the mind as if something very important misses in your life.

- Required: One must understand that achieving a goal is not an option but a must. If a goal is perceived to pay off in the future, one is likely to be more attracted to it and to act with more urgency to make it happen.

- Difficult: Setting goals that are so 'hard' as to tap all your talents to enable their achievement. However, they should not be so hard that you may not be able to attain them.

The implication of MBO for school management in a decentralised authority through OPRAS, as is also the case for the tradition of liberalism and market mechanisms, is that teachers should be given more power to allocate resources (Lauglo, 1995, p. 22) and more freedom to choose the means through which to attain the objectives in accordance with their own priorities and preferences. Thus, it can be argued that since people at the local level (in this case teachers) have more knowledge of local conditions (Communities and Local Government Committee [CLGC], 2011, p. 19) than do central decision makers, they are better placed to set their own priorities and would thus feel a sense of commitment to and ownership of the objectives. Giving teachers the power to decide on matters that affect their lives (World Bank [WB], 2003, p. 74), including managing their own schools, may therefore improve resource utilisation and allocation. According to Lauglo (1995, p. 18), MBO, like the now old-style scientific management (SM), places the emphasis on the specificity of tasks, but as defined by objectives and not (as in SM) by rules and regulations that specify how tasks should be carried out. Lauglo further states that MBO assumes the importance of group solidarity for productivity, as did the human relations school of management that was subsequent to SM.

The central focus of MBO, however, has been on 'objectives or goals'. Khabakuk and Shkliarevsky (1982, p. 115) observe that the new features of $\mathrm{MBO}$ are intended to give better integrity and systematic characteristics to management. According to Gaynor (1998, p. 20), teacher representation on promotion panels, including the assurance that they are involved in setting of acceptable standards of performance, helps in solving the problems at school level. Gaynor (1998, p. 22) suggests that if the aim is to improve teachers' performance, teachers need to have some mechanisms to raise their grievances or complaints to higher levels of administration. To Gaynor, the decentralisation of responsibility in terms of disciplining the teachers, without creating an environment conducive for its proper implementation, will create unnecessary conflict between headteachers and teachers. As observed by Hargreaves (2006, p. 673):

Overworked and underpaid teachers have had to master and comply with centrally imposed learning standards, detailed curriculum targets and pervasive testing regimes - and they have seen their work and their worth become broken down and categorised into checklists of performance standards or competencies. All these conflicting pressures and tendencies are leading teachers and those who work with them to re-evaluate their professionalism and to make judgments about the kind of professional learning they need to get better in their job. 
According to Ranson (2003, p. 199), "If teachers are required to account to parents about the progress of their children, they in turn can have legitimate expectations that carers reinforce the learning process". Furthermore, Gaynor (1998, p. 30) states that to be effective regarding teacher appraisal systems, an understanding of the local context (school realities and priorities) is essential when setting the objectives.

While recognising the importance of focusing on the objectives and goals, however, MBO could also adversely affect the creativity of workers, in this case, teachers. Since 'objectives' tend to be defined in narrow terms, in mastering highly specified tasks, risk such tasks being achieved at the expense of a more holistic 'understanding'. This might result in superficial and insufficiently holistic knowledge among the pupils when working against the objective of passing examinations.

\section{Literature review}

\subsection{New public management (NPM) theory}

NPM "is the theory that makes contracting the medium of communication in the public sector" (Lane, 1999, p. 180). According to Aucoin (1990) cited in Hood (1995, p. 95), NPM is a public-management system that stresses a mix of the public and private sector in its operations. It has been introduced in many Organisation for Economic Cooperation and Development (OECD) member countries since the late 1970s and early 1980s (Hood, 1995, p. 93; Gruening, 2001, p. 2). NPM focuses on MBO in the public sector and opens for public-private partnerships by means of contracts. The main NPM goals are:

- Improving public-sector efficiency and effectiveness in service provision;

- Enhancing public agencies' focus on customer satisfaction;

- Reducing public expenditure or budget cuts, e.g. by means of contraction;

- Improving managerial accountability among public servants (Christensen and Lægreid, 2011, p. 1).

The shift towards NPM was part of the broader change in the doctrine of public accountability from the one which previously marked public administration in countries such as the USA during its 'progressive era' (Hood, 1995, p. 93; Marsden, 2009, p. 3). The earlier focus of the accountability movement in the USA was on the fight against corruption, specifically against the use of public office for personal gain (Hood, 1995, p. 94). According to Hood, a mix of 'hightrust and low-trust relationships' is the major feature of the current accountability movement in the public service. The belief is that efficiency and effectiveness in service delivery in the workplace can be enhanced by means of contracts (Lane, 1999, p. 180; Ranson, 2003, p. 204).

In the NPM system, government planners are no longer exclusively responsible for public-sector service delivery (McLaughlin, Osborne and Ferlie, 2002, p. 10). McLaughlin et al. contend that the provision of services and the management of educational planning involve a number of actors, such as the government itself, volunteer groups, community sectors and other sectors in the private domain.

According to Hood (1995, pp. 93-94), the accountability paradigm of progressive public administration (PPA) under the NPM emphasises two basic doctrines of management. First, it keeps the public sector distinct from the private sector in terms of its methods of operation, career structure and other reward-related issues. Second, the public sector is safeguarded against favouritism and corruption in service provision. This also has a bearing on current conditions in Tanzania due to the widespread corruption practices.

\subsection{Features of NPM theory}

There are various features of NPM. For this paper, only six of them that are particularly relevant are displayed in Table 1 and explained in more detail below in terms of their core operational significance.

\subsubsection{Professional management in the public sector}

NPM stresses the need for public officials to be professional and accountable for their actions by fulfilling their responsibilities. To be professional, as stated by Sockett (1976, p. 35), means performing according to the required rules and regulations and fulfilling obligations as an employee. In addition, professionals are also accorded much autonomy in making judgements about practice within such rule structures because of their occupational-socialisation process in which they have acquired expertise that non-professionals do not possess.

According to Sockett (1985, p. 3), "A profession is said to be an occupation with a crucial social function, requiring a high degree of skill and drawing on a systematic body of knowledge". Hargreaves (2006, p. 673) further argues: "To be professional has to do with how teachers feel they are seen through other people's eyes - in terms of their status, standing, regard and levels of professional reward". To Hargreaves, an attempt to improve the status and standing of the teaching profession is what is termed as professionalisation. The process may help with the process of careful budgeting as well as in facilitating the proper utilisation of the available scarce resources. 
Table 1. Features of new public management

\begin{tabular}{|c|c|c|}
\hline Feature & Justification & Core operational significance \\
\hline $\begin{array}{l}\text { Emphasis on professional } \\
\text { management in the public sector }\end{array}$ & $\begin{array}{l}\text { A need for accountability that fulfils } \\
\text { the assignment of responsibility of } \\
\text { action and prevents a diffusion of } \\
\text { power }\end{array}$ & $\begin{array}{l}\text { Devolved budgets and greater } \\
\text { delegation of decision-making in } \\
\text { resource utilisation }\end{array}$ \\
\hline $\begin{array}{l}\text { 2. Contracting system for } \\
\text { competitive provision and } \\
\text { delivery of services }\end{array}$ & $\begin{array}{l}\text { A need for defined goals, targets and } \\
\text { performance indicators by using } \\
\text { contracts for professional service in } \\
\text { order to lower the operating costs and } \\
\text { to improve performance and } \\
\text { standardised results }\end{array}$ & $\begin{array}{l}\text { Emphasis on clear statements and } \\
\text { goals for more efficiency and } \\
\text { effectiveness in achieving goals and } \\
\text { objectives }\end{array}$ \\
\hline $\begin{array}{l}\text { 3. Output control by employing } \\
\text { private-sector management styles } \\
\text { and practices }\end{array}$ & $\begin{array}{l}\text { A need for result-based performance } \\
\text { and application of private-sector } \\
\text { management tools in the public-sector } \\
\text { system }\end{array}$ & $\begin{array}{l}\text { Enhanced allocation of resources and } \\
\text { better employee performance linked } \\
\text { to employee rewards, payments and } \\
\text { entitlements }\end{array}$ \\
\hline $\begin{array}{l}\text { 4. Fostering discipline in the } \\
\text { utilisation of the meagre } \\
\text { available resources by } \\
\text { decentralising the budget }\end{array}$ & $\begin{array}{l}\text { Cutting off the direct costs and raising } \\
\text { labour discipline }\end{array}$ & $\begin{array}{l}\text { Creation of management units for } \\
\text { more efficient service provision and } \\
\text { to capitalise on the contractual } \\
\text { advantages in both the private and } \\
\text { public sector }\end{array}$ \\
\hline $\begin{array}{l}\text { 5. Creating a competitive public } \\
\text { sector in terms of service } \\
\text { provision }\end{array}$ & $\begin{array}{l}\text { Terminal contracts with renewal of } \\
\text { the contract based on satisfactory } \\
\text { service for enhanced accountability }\end{array}$ & $\begin{array}{l}\text { More freedom in management styles } \\
\text { using discretionary power vested in } \\
\text { the individual }\end{array}$ \\
\hline $\begin{array}{l}\text { 6. Explicit measurement of } \\
\text { performance standards and } \\
\text { success }\end{array}$ & $\begin{array}{l}\text { The need for accountability and } \\
\text { efficiency of the stated aims, goals } \\
\text { and targets by means of inspection } \\
\text { and audit systems }\end{array}$ & $\begin{array}{l}\text { Eliminating self-management by } \\
\text { professionals }\end{array}$ \\
\hline
\end{tabular}

Source: Compiled from Hood (1991, pp. 4-5); Hood (1995, p. 96); Gruening (2001, p. 2)

However, if professionals are assumed to have superior expertise, they should be given considerable autonomy to deal with professional tasks - subject to rules and regulations devised by professionals themselves, when lay people are not in a good position to assess the quality of the service rendered.

\subsubsection{Contracting of employment terms}

Contracting is assumed to enhance efficiency in service provision and provide competition so that people have a choice of alternative provisions (public or private). In the case of education, parents would be more likely to send their children to a school where they think the children will get a good education. An employee has to pursue the defined goals and targets using performance indicators identified in the contract when offering professional services. By so doing, it is thought that efficiency and effectiveness in achieving goals and objectives will be enhanced.

\subsubsection{Output control}

NPM focuses on results-based performance indicators as applied in the private-sector management systems. This is done to ensure that the available resources are properly allocated and utilised for better performance. Employees are rewarded for good performance with payments and entitlements. Their annual salary increment and promotion prospects will, ideally, depend on the extent to which the organisational targets and objectives are met.

\subsubsection{Decentralised budget}

NPM stresses the decentralised budgeting of available resources. This aims at minimising direct costs and at safeguarding employee discipline in the utilisation of scarce resources. Thus, NPM purports to improve efficiency in managing organisational units. It also assumes the benefit of agreements (contracts) to reach formally agreed objectives for both private- and public-sector activities.

\subsubsection{Competitive mechanisms}

NPM assumes the benefit of greater competition in the public sector. Fixed-term contracts are thought to be desirable as an incentive for service delivery by making contracts subject to renewal, based upon satisfactory performance after a specified period. Through this mechanism and performance indicators, NPM is assumed to foster accountability for one's performance. Such fixed-term contracts have not become common public services under the application of NPM, but the public sector may make more use of sub-contracting (outsourcing) of service provision. Individual employees are required to adhere to the agreements against targets and resources allocated for an activity. This is considered to 
improve freedom by reducing the scope for arbitrary rule-of-thumb management. On the other hand, under NPM, public servants need to apply their discretional judgment to accomplish the set goals and objectives.

\subsubsection{Explicit measurement of performance}

The argument for NPM is that the measurement of performance is to be based on 'acceptable standards' with reference to stated aims, goals and targets and that it uses inspections or audit mechanisms to make individuals responsible for their actions and their delivery of satisfactory services. The question is who is to define what the acceptable standards are and what kind of process is needed?

Proponents argue that NPM is cost effective and can improve efficiency for public and non-profit management, and that it can help to address fundamental management weaknesses such as inadequate accountability and control of public services (Lane, 1999, p. 184). Opponents argue that NPM risks weakening professional autonomy and morale, and that the quality of professional work is not well-enough captured by the types of indicators typically devised under NPM. Some have the view that the system may work in developed societies when sufficient resources are available (McLaughlin et al., 2002, p. 11). It is unlikely to do so in developing countries where human and financial resources are scarcer, and where NPM, therefore, is more difficult because of difficulties in setting objectives, for example, in terms of performance indicators.

\subsection{Open Performance Review and Appraisal System in Tanzania}

As part of Management by Objective, OPRAS was introduced in Tanzania in 2004. OPRAS aimed at improving service delivery and effectiveness and efficiency in the public sector (Issa, 2010, p. 5). The programme was a response to poor service delivery and lack of accountability among service providers to the clients. Its central focus was on results-based performance and accountability in public services.

In this system, public officials are accountable for their performance based on indicators of performance and resources. OPRAS was introduced in 2004 and implemented in government offices in 2005 (Bana, 2009, p. 12). According to Issa (2010, p. 9), "OPRAS is a system which requires every public servant to sign an individual performance agreement with his/her immediate supervisor which sets performance targets per year". It has been part of the broader publicsector employment reform termed the Public Service Reform Programme (PSRP), with the purpose of improving service delivery in the public-service system. Workers, including teachers, are to sign contracts with their immediate bosses/superiors relating to performance criteria and objectives to be achieved (Issa, 2010, p. 5).

The OPRAS agreement is the basis for employee-performance appraisal at the end of the year (Issa, 2010, p. 9). The employee has to be assured of the availability of resources to facilitate his/her performance. At the end of the year, the worker is to be evaluated/measured using performance indicators for the agreed terms of reference as criteria for her/his promotion or demotion. The assumption was that this new management system would enhance partnerships in the organisation and hence results-based performance and improved accountability in the public sector. Educational Circular No. 2 of the Public Service stipulates four important procedures in setting the performance objectives:

- There should be specific objectives of work performance for the whole year for each individual public servant;

- The public servant and the immediate supervisor should agree on the objectives to be attained as a basis for the contract between them;

- Specific objectives should be formulated based on the general objectives in the strategic plan of the particular institution;

- Each public servant must be involved in planning and setting the objectives for her/his performance and should have a clear understanding of the personal and institutional objectives.

Teachers, for example, are to sign the OPRAS contract with their school heads. The school headteachers are to sign a contract with the Ward Education Coordinator (WEC) ${ }^{1}$, who should sign the contract with the District Education Officer (DEO). The DEO has to sign a contract with the city/district director, who also signs the contract with the mayor of the city or the chairperson of the council (as representatives of the city or district council). The council members are elected from the different wards as a way of increasing the accountability of school operations and other functions of the district councils.

Accountability of teachers to the pupils' leaning has been stated in PEDP document as follows:

\footnotetext{
1 The WECs are promoted headteachers who are given the responsibility of supervising teachers in their areas of jurisdiction. An academic ward involves two to four schools. WEC offices are within the office of the ward executive officer (WEO). Under the decentralised plan, the WECs have been given more power to supervise teachers' work performance as a mechanism for accountability in educational delivery.
} 
It is clear that the school is accountable to its pupils/students. Students are the clients of the school and as such it is essential that they benefit from the education the school provides. The school is accountable to the parents of the pupils/students. In this respect the parents must be assured that the schools are doing a good job. The school is accountable to its school committee/board, which has invested time and resources. It needs to be assured that quality education is being provided. In broad terms, the schools are accountable to the community at large. The country needs to be assured that the overall investment in education is worthwhile, that children are being well educated and that the government and owners/managers of schools are getting value for money which they have invested in schools (URT, 2001, p.58).

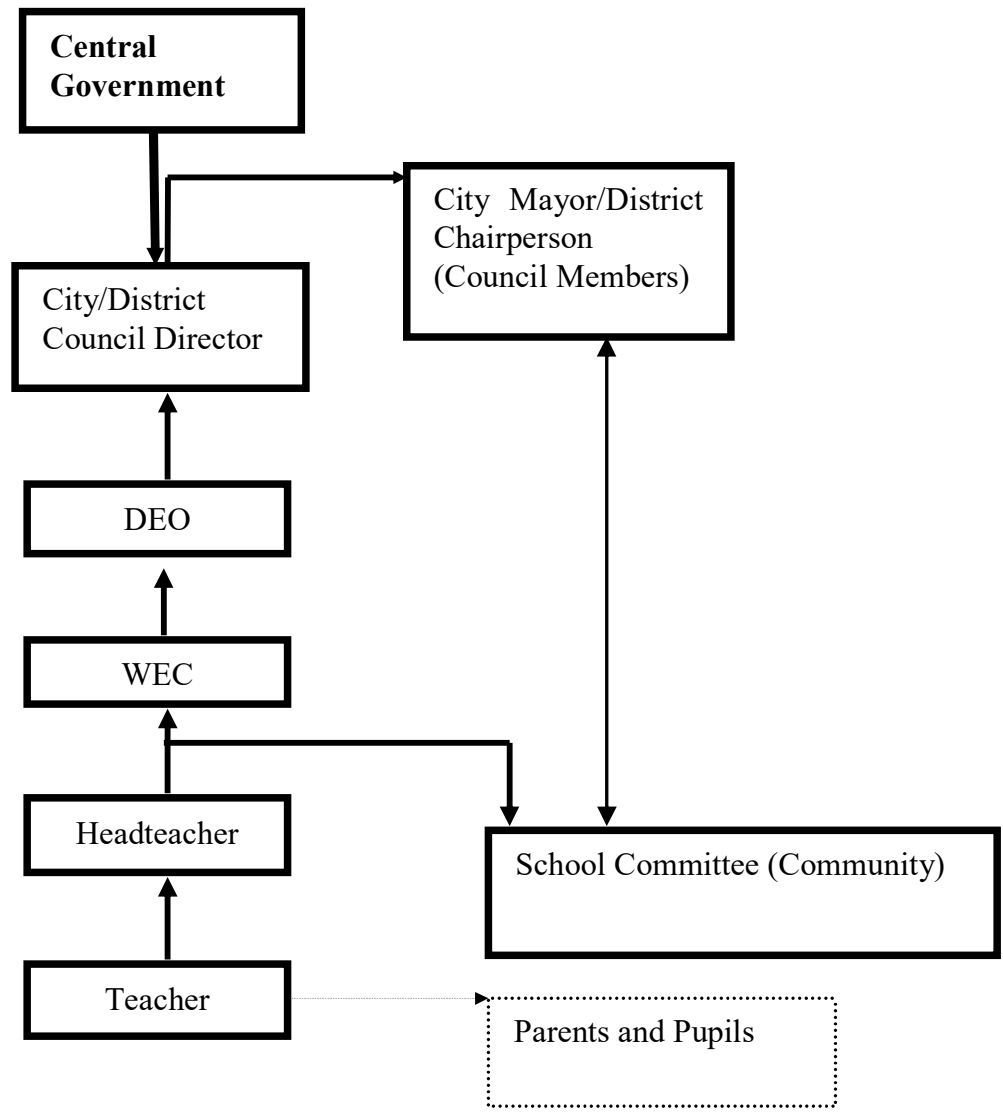

Figure 1. Accountability lines in Tanzanian education

The authority is decentralised from the central government to the city/district director, and the city/district director is accountable to the city mayor/district chairperson. The District Education Officer (DEO) is answerable to the city/district director, although the process does not follow the same line of command of authority. All other decentralised offices function according to an upwards or bottom-up accountability line that may respond more to different types of delegation of authority. A teacher is accountable to the hierarchy (upwards) and also to the school committee (community) through the headteacher and sometimes indirectly to the parents and pupils through meeting their learning needs. The mutual interaction between the council and school committee members is important for improving the conditions in schools (see figure 1).

It was the aim of this study to find out how teachers perceive the OPRAS contract as means of assessing their work performance and their accountability for their teaching with regard to performance-based outcomes.

\section{Research Method}

The study was basically qualitative, although quantitative data were also used especially when considering the frequencies and percentages from questionnaires. The main reason for choosing mainly qualitative approach was to obtain a deeper understanding of the teachers' lived experiences with regard to OPRAS. The study was carried out in two selected regions, Kinondoni Municipality in Dar es Salaam and Mbeya City in the Mbeya region. Dar es Salaam is the permanent base of the central government bureaucracy. Almost all ministries are located in this city and many of the policy documents (circulars) for this study were obtained at the Ministry of Education and Vocational Training (MoEVT). Mbeya region was selected because Mbeya City was the leading district in the Primary School Leaving Examination (PSLE) results at the national level for three consecutive years from 2003-2005. In 2006 and 2007, it held the fourth position at the national level and the first at the regional level. However, the PSLE performance of the pupils 
in the region and particularly in Mbeya City has reportedly declined more recently relative to other regions. Thus, I wanted to find out what had gone wrong. Could OPRAS help to improve the teachers' work performance? The sample included 90 teachers, 10 headteachers, 6 school committee members in the selected primary schools and 2 DEOs. The schools were purposefully selected, where 3 schools in Dar es Salaam were selected from peri-urban area and 2 from urban area. In Mbeya City, 3 schools were from urban area and 2 schools from peri-urban area. Because the number of teachers in the visited schools was less than the targeted one, then all the teachers available during the school visit were included in the study. The headteachers and the educational officials were selected purposefully as it was believed that they had the information in need. The methods of data collection involved the questionnaires and interviews supplemented by documentary review. The data analysis was carried out by using Statistical Package for Social Sciences (SPSS) for frequencies and percentages and the multiple codes and voices of the informants to establish the pattern and thematic analysis.

\section{Results}

\subsection{Effects of OPRAS contract for evaluation of teachers' work performance}

During the school visit in both Dar es Salaam and Mbeya, a half (47\%) of the teachers indicated that they had not signed the OPRAS contract, and only few teachers (40\%) had signed the contract with their headteachers (Table 2). Almost all of the headteachers in Mbeya City had signed the contract with their WECs and just a few in Kinondoni Dar es Salaam had done so. However, the OPRAS forms had not been used for quite a long time.

Table 2. Teachers who had signed the OPRAS contract or not signed

\begin{tabular}{|c|c|c|c|c|c|}
\hline Question asked & Region \& location & $\mathrm{S}$ & Signed & Not signed & Total \\
\hline \multirow{10}{*}{$\begin{array}{l}\text { Did you sign an OPRAS } \\
\text { contract with your } \\
\text { headteacher with agreed } \\
\text { criteria for your work } \\
\text { performance? }\end{array}$} & MBY-peri-urban & $\mathrm{A}$ & 3 & 5 & 8 \\
\hline & DSM-peri-urban & $\mathrm{B}$ & 6 & 0 & 6 \\
\hline & DSM-peri-urban & $\mathrm{C}$ & 3 & 7 & 10 \\
\hline & DSM-urban & $\mathrm{D}$ & 0 & 5 & 5 \\
\hline & MBY-urban & $\mathrm{E}$ & 2 & 6 & 8 \\
\hline & MBY-urban & $\mathrm{F}$ & 0 & 10 & 10 \\
\hline & DSM-peri-urban & G & 8 & 1 & 9 \\
\hline & DSM-urban & $\mathrm{H}$ & 4 & 6 & 10 \\
\hline & MBY-urban & I & 5 & 1 & 6 \\
\hline & MBY-peri-urban & $\mathrm{J}$ & 5 & 1 & 6 \\
\hline \multicolumn{2}{|c|}{ Grand total } & & $36(40 \%)$ & $42(47 \%)$ & $78(87 \%)$ \\
\hline
\end{tabular}

One of the headteachers from school ' $F$ ' stated during the interview:

The OPRAS form did not help us, as it was not used for teacher promotion. The Teachers' Service Department promotes teachers and so they do not see the necessity of using OPRAS forms. We started using the forms in 2005 up to 2008 . No teachers were promoted using the forms.

Another headteacher from school '

OPRAS forms were stopped because teachers were complaining about having so many pupils in their classrooms and lacking teaching and learning facilities such as books. If facilities had been available, maybe the forms could have worked in a positive way. Now it has been so difficult. At the end of the year you find that many pupils do not know how to read and write.

There has been no official letter to stop OPRAS, but teachers have boycotted it and the Teachers' Trade Union (TTU) did not agree with its implementation for teachers. A headteacher in school 'E' stated during the interview: "We stopped filling in the OPRAS forms about three or four years ago. The teachers did not understand them and no teacher was promoted using the forms". When asked about the advantages and disadvantages of the forms, he commented:

If its implementation had been proper and teachers had learned how to use the forms and how to fill them in, it could have some advantages. But the teacher teaches about 80,90 or 100 pupils in the classroom. Those pupils are too many for a single class. If there had been 45 pupils in a class, it would have been easier for a teacher to teach them and so it would have been easier as well to measure teacher 
accountability in teaching the pupils. Yet, each individual teacher has about 22 periods per week, and this is because we have been accommodating so many pupils in a single classroom. Otherwise, teachers could have many periods, even 40 periods per week.

Table 3. Effect of OPRAS on teachers' work performance

\begin{tabular}{|c|c|c|c|c|c|c|c|c|c|c|c|c|}
\hline \multirow[t]{2}{*}{ Effects } & \multicolumn{10}{|c|}{ School } & \multirow[t]{2}{*}{ Freq. } & \multirow[t]{2}{*}{$\%$} \\
\hline & A & $\mathrm{B}$ & $\mathrm{C}$ & $\mathrm{D}$ & $\mathrm{E}$ & $\mathrm{F}$ & G & $\mathrm{H}$ & I & $\mathrm{J}$ & & \\
\hline Wastage of time & & & & & 1 & 1 & & & & & 2 & 2 \\
\hline A deceiving mechanism & & & & & 1 & 2 & & & & & 3 & 3 \\
\hline Leads to sexual harassment & & & 1 & & 1 & & & 1 & & & 3 & 3 \\
\hline $\begin{array}{l}\text { Enhances teacher } \\
\text { accountability }\end{array}$ & & 1 & 1 & & 3 & & & & 2 & 1 & 8 & 9 \\
\hline Creates fear among teachers & & 2 & & & 1 & & & & & & 3 & 3 \\
\hline No effects & 7 & & & & 1 & & & & 2 & 3 & 13 & 14 \\
\hline Sub-total & 7 & 3 & 2 & & 9 & 3 & & 1 & 4 & 4 & 32 & 36 \\
\hline No answer & 3 & 7 & 8 & 6 & 2 & 7 & 9 & 9 & 2 & 5 & 58 & 64 \\
\hline Grand total & 10 & 10 & 10 & 6 & 10 & 10 & 9 & 10 & 6 & 9 & 90 & 100 \\
\hline
\end{tabular}

Source: Field data (2011)

More than half of the teachers (64\%) from almost all of the visited schools in Kinondoni and Mbeya City saw no effect from the contract (Table 3). This may be because many of the teachers had not been asked to sign it. Some teachers said that it did not affect them because they could not work according to the requirements due to lack of facilities. One of the teachers from school ' $G$ ' (Q 75) said: "I cannot accept signing the contract because my work environment is very difficult and we have a big number of pupils in the classrooms who sit on the floor". Another teacher from the same school ' $G$ ' (Q 69) stated:

I cannot accept the OPRAS contract as I teach quite a big number of pupils, more than what I have been prepared for. If they build enough buildings and the number of pupils in the classrooms does not exceed 45, I will accept signing it.

A teacher from school ' $F$ ' (Q 2) stated:

The teacher should be left free to teach. When you have a lot of follow-ups, the teacher will concentrate on what is valued most and not on teaching in a wider sense. The focus will be on accomplishing the objectives but not considering pupils' understanding.

Those who did not sign the contract, mostly from the Dar es Salaam region, indicated that it was expensive because of the need to duplicate copies of OPRAS forms and that it took time to fill in and to discuss with the headteacher. Others expressed how it created hostility between the headteacher and teachers, especially when the headteacher was open about the poor performance of the teacher. A teacher from school ' $\mathrm{C}$ ' (Q 64) commented:

OPRAS had no good results. It was discovered that many headteachers used it with bias and favouritism. Those teachers who did not have good relationships with their headteachers were given a bad evaluation and received low ratings at the end of the year.

However, some of the teachers said that the OPRAS contract, if well worked out, could improve performance and efficiency in teaching and learning. They also thought that OPRAS could help improve communication between the employer and employee. There are teachers who thought that OPRAS reminded workers, including teachers, of their responsibility at work. One of the teachers from school ' $E$ ' (Q 12) commented: "This contract is good as it enables teachers to work hard and it makes teachers accountable in their teaching because it helps achieve the objectives that you set on your own". A teacher from school 'C' (Q 77) stated: "OPRAS should continue as it enhances accountability by making everyone work harder because no one would like to be downgraded”. Another teacher from school ' $\mathrm{C}$ ' $(\mathrm{Q}$ 66) said:

The OPRAS contract has helped me to work hard to accomplish the objectives that were set with the headteacher. However, this contract is difficult to put into practice in the Tanzanian primary school 
environment because we do not have resources to implement the agreed objectives and most of the pupils are congested in classrooms with massive shortage of desks.

In some schools, teachers said that they had signed the contract while others had not. This may be because some teachers resented the contract, which they found to be unrealistic under the conditions of congested classrooms with pupils sitting on the floor and with shortages of textbooks. In such circumstances, no matter how well the teacher performs, many of the pupils may complete standard-VII without mastering such important basic skills as writing, reading and simple calculations.

\section{Discussion}

From the findings on teachers' views on OPRAS, there seems to be two groups of teachers: the pessimistic group that thinks that the contract will ruin their freedom and that it is not practical in the Tanzanian environment, and the optimistic group who wants change. Most teachers seem to be pessimistic and would like it to be removed, as it does not work well enough given their working conditions and the situation in primary schools. To teachers, OPRAS was impractical attempt in primary schools because of the massive shortages of desks, classroom spaces, and textbooks; and other teaching and learning materials and facilities. OPRAS was, however, still used for government officials in other cadres. Recently, from 2013 teachers have started signing the OPRAS again and it has been introduced at University level.

While it is evident that the majority of teachers oppose the use of OPRAS; however, teachers need to understand that they live in the New Public Management (NPM) regime where accountability and management by objective is needed than ever before. In this accountability regime, where the quality education is needed than any other investment (Becker, 2006, p. 292), OPRAS contract may play an important role in improving the work performance of teachers. As a result, teachers need not only to be creative but also they will need to apply the results-based kind of performance. As Brim states, they will need to focus on attainable objectives (SMART), from which their accountability for their teaching will be measured for the better pupils' academic performance (Ballard and Bates, 2008, p. 560).

In this competitive age where parents are more concerned with education of their children that may help them to succeed in future, teachers will need to fulfill their obligations and demonstrate a sense of responsibility of helping the pupils to learn and acquire knowledge and skills that are needed in this post-modern era. It is the fulfillment of their responsibility as teachers that will ideally, justify their sense of commitment to the society they serve and the pupils they teach (Neave, 1987, p. 77). As stated by Ball (2003, p. 220), when teachers become more uncertain about their actions and face all these pressures in their profession, they need to reflect and ask themselves:

Are we doing this because it is important, because we believe in it, because it is worthwhile? Or is it being done ultimately because it will be measured or compared? It will make us good! Do we know we are good at what we do, even if performance indicators tell a different story? Do we value who we are able to be, we are becoming in the labyrinth of performativity.

\section{Conclusion}

Management by Objectives through OPRAS contract has been received by teachers with diverse perspectives. There are teachers who see that OPRAS can help them perform based on their own planned specific objectives and those teachers who see that OPRAS will work at the detriment of their rights. Teachers have to understand that most governments in the world in this postmodern era are highly concerned about the education of their citizens. There has been also an increased pressure and attention from many different groups in society and parents to ensure that their children receive quality education that will enable them to compete in the labour market economy. Thus, the NPM system that emphases a performance-based outcome has been advocated for ensuring that service providers meet and satisfy the demands of the customers.

While evaluation of teachers is important, the adoption of the type of assessment for their work performance has to be considered because of the nature of the field and the complications involved in dealing with human mind. Teaching is a labour-intensive process. Teachers cannot, by means of their teaching, determine how many pupils will pass a given exam and how well they will do in their exams. The impacts of teaching take a long time to manifest themselves and are difficult to measure, unlike in industries where it is possible to measure performance, for example, whether a machine designed to produce 100 bags of salt or cement will actually produce this number, and where it is easier to identify the reasons for shortfalls. Thus, the reflection of local environment and conditions in which teachers work needs consideration (Gaynor, 1998, p. 30), if the aim is to improve their work performance and accountability for their teaching.

To be effective in raising teacher's performance through OPRAS, it is important to ensure that teachers are motivated to do their job. Schools must be provided with resources and must be able to decide on their use in accordance with local needs, although a balance in such a democracy is also important to ensure the achievement of objectives. 


\section{References}

Ball, S. (2003). The teacher's soul and the terrors of performativity. Journal of Education Policy, 12 (2), 215-228.

Ballard, K. \& A. Bates (2008). Making a connection between student achievement, teacher accountability, and quality classroom instruction. The Qualitative Report, 13 (4), 560-580.

Bana, B. (2009). Performance management in Tanzania public service. A paper presented at the Conference on Governance Excellence: Managing Human Potential. Arusha International Conference Centre. Dar es Salaam: United Republic of Tanzania.

Becker, G. (2006). The age of human capital. In Lauder, Hugh, Phillip Brown, Jo-Anne Dillabough and A. Halsey (Eds.). Education, Globalization \& Social Change. Oxford: Oxford University Press.

Brady, R. (1973). MBO goes to work in the public sector. Journal of nursing administration, 3 (4), 44-52.

Brim, R. (2012). A history of MBO and recommendations for today's managers: Helping people be productive. From MBO to DEMING to project management and beyond. White paper prepared on performance solutions technology, LLC.

Christensen, Tom and Per Lægreid (2011). Introduction. In Christensen, Tom and Per Lægreid (Eds.), The Ashgate research companion to new public management. England: Ashgate Publishing Limited.

CLGC (2011). Localism: Third report of the session 2010-2012. London: The House of Commons.

Errey, C. (2006). Management by objectives and IT projects. The performance technologies group PTG Global, 1-6.

Gaynor, C. (1998). Decentralization of education: teacher management. Washington, D.C.: World Bank.

Gruening, Gernod (2001). Origin and theoretical basis of new public management. International Public Management Journal, (4), 1-25.

Hargreaves, A. (2006). Four ages of professionalism and professional learning. In Lauder, Hugh, Phillip Brown, JoAnne Dillabough and A. Halsey (Eds.), Education, Globalisation \& Social Change. New York: Oxford University Press.

Hood, C. (1991). A Public Management for All Seasons? Public Administration, 69, 3-19.

Hood, C. (1995). The "New public management" in the 1980s: variation on a theme. Accounting Organisation and Society, 20, (2/3), 93-109.

Issa, F. (2010). Policy and methodologies for evaluating performance of the public service in Tanzania. A Paper presented at the expert group on human resources management policy in the public sector in Africa held in Durban, South Africa.

Khabakuk, M. \& G. Shkliarevsky (1982). International studies of management and organisation. The Science of Management in the USSR, 11, (3/4), 113-122.

Lane, J. (1999). Constractualism in the public sector. Public management review, 1, (2), 179-194.

Lauglo, J. (1995). Forms of decentralisation and their implications for education. Comparative Education, 31, (1), 5-28.

Marsden, L. (2009). Does the middle class call for government accountability? The progressive era American middle class versus the new Chinese middle class. SAIS China studies-student working paper series.

Mclaughlin, K., S. Osborne \& E. Ferie (Eds.) (2002). New public management: Current trends and future prospects. London: Taylor \& Francis group.

Neave, G. (1987). Accountability in education. In Psacharopoulos, George (Ed.), Economics of education-research and studies. Oxford: Pergamon press.

Ranson, S. (2003). Public Accountability in the Age of Neo-Liberal Governance. Journal of Education Policy and Politics, 18 (5), 459-480.

Sockett, Hugh (1985). Towards a professional code of teaching. A paper presented at the annual meeting of the American educational research association. Chicago, March 31-April 4.

Thomas, M. (1998). Management by objectives. $2^{\text {nd }}$ Edition. Jossey Bass/Pfeiffer.

URT (2001). Primary education development plan (2002-2006). Dar es Salaam: MoEC.

World Bank. (2003). World development report 2004: Making services work for the poor. Washington, D.C.: World Bank. 